\title{
Rancang Bangun Alat Peringatan Dini Dan Informasi Lokasi Kebakaran Berbasis Arduino Uno
}

\author{
Novaldiyanto K. Nento \\ Prodi Teknik elektro \\ Universitas Negeri Gorontalo \\ Gorontalo, Indonesia \\ noval_gbjcrew@yahoo.co.id
}

\author{
Bambang Panji Asmara \\ Prodi Teknik elektro \\ Universitas Negeri Gorontalo \\ Gorontalo, Indonesia \\ Bambang@ung.ac.id
}

\author{
Iskandar Z. Nasibu \\ Prodi Teknik elektro \\ Universitas Negeri Gorontalo \\ Gorontalo, Indonesia \\ zul.nasibu@ung.ac.id
}

$\begin{array}{ll}\text { Diterima } & \text { : Desember } 2020 \\ \text { Disetujui } & \text { : Desember } 2020 \\ \text { Dipublikasi } & \text { : Januari } 2021\end{array}$

Abstrak -- Bahaya kebakaran adalah bahaya yang diakibatkan oleh adanya ancaman potensial dan derajat terkena pancaran api sejak dari awal terjadi kebakaran hingga penjalaran api, asap dan gas yang ditimbulkan. Kebakaran adalah terjadinya api yang tidak dikehendaki. Proses informasi adanya kebakaran pada umumnya masih memakai cara manual, hal ini dilakukan karena belum memanfaatkan kecanggihan teknologi yang sekarang ini sangat berkembang pesat. Informasi kebakaran ini kurang cepat dan tepat khususnya pada satuan pemadam kebakaran. Tujuan dari penelitian ini adalah merancang sistem yang dapat digunakan untuk menginformasikan kebakaran dengan cepat beserta informasi lokasi pada tempat terjadinya kebakaran. Metode yang digunakan dalam penelitian ini yaitu metode eksperimen dan perancangan baik dalam pembuatan perangkat keras serta perangkat lunak pendukungnya. Perangkat kerasnya menggunakan sensor api, sensor asap dan sensor suhu, dan menginformasikan melalui modul GSM serta modul GPS untuk membaca koordinat lokasi kebakaran. Hasil dari perancangan alat peringatan dini dan informasi lokasi kebakaran berbasis arduino uno bekerja dengan baik. Pada alat pengirim, saat kondisi ada api, ada asap dan suhu diatas 50 derajat alat mengirimkan sms untuk menyalakan alat penerima dan sms link google maps lokasi kebakaran. Pada alat penerima, saat alat menerima sms dari alat pengirim, alat akan menyalakan buzzer. Alat bekerja sesuai dengan yang telah direncanakan dan bisa digunakan untuk mendeteksi adanya kebakaran.

Kata kunci : sensor, modul GSM, GPS, arduino

Abstract - Fire hazard is a danger that is caused by the potential threat and the degree of exposure to fire from the start of a fire to the spread of fire, smoke, and the gas it causes. Fire is a fire incident that is not desired. In general, the information process for fires still uses the manual method, this is done because it has not taken advantage of the sophistication of technology which is now very rapidly developing. This fire information is not fast and accurate, especially for fire fighting units. The purpose of this research is to design a system that can be used to quickly inform fires along with location information at the scene of the fire. The method used in this research is the experimental method and design both in hardware and supporting software. The hardware uses fire sensors, smoke sensors, and temperature sensors, and informs via GSM module as well as the GPS module to read the coordinates of the fire location. The results of the design of early warning tools and fire location information based on Arduino Uno worked well. On the sending device, when there is a fire, there is smoke and the temperature is above 50 degrees, the device sends an SMS to the receiving device and the SMS link on the google maps location of the fire. On the receiving device, when the device receives an SMS from the sending device, the device will create a buzzer. The tool works as planned and can be used to check for fires.

Keywords: sensor, GSM module, GPS, Arduino

\section{PENDAhuluan}

Dalam berkehidupan bermasyakat, hidup rukun, damai serta ditunjang dengan keamanan lingkungan sangat diharapkan oleh masyakata. Menyangkut keamanan dilingkungan sekitar rumah ataupun perumahan adalah kebakaran. Peristiwa yang tidak diinginkan oleh masyarakat adalah kejadian atau perisiwa kebakaran yang biasanya tidak dapat dikendalikan. Menurut Badan Nasional Penanggulangan Bencana (BNPB) bencana adalah "peristiwa atau rangkaian peristiwa yang mengancam dan mengganggu kehidupan dan penghidupan masyarakat yang disebabkan oleh faktor alam, faktor non-alam, ataupun faktor manusia sehingga mengakibatkan timbulnya korban jiwa, kerusakan lingkungan, kerugian harta benda dan dampak psikologis.[1]

Kebakaran itu sendiri adalah suatu kejadian yang tidak dikehendaki yang menimbulkan api. Bagi sebagian penghuni ataupun pemilik rumah, malapetaka yang sangat merugikan bagi pemilik rumah adalah kebakaran, karena 
dapat berakibat pada trauma, cacat fisik, kerugian materi dan material bahkan sampai kehilangan pekerjaan

Kebakaran rumah merupakan salah satu kecelakaan yang paling sering terjadi untuk propinsi gorontalo sepanjang tahun 2019 saja sebanyak 72 kejadian atau peristiwa kebakaran sumber informasi Harian Gorontalo tanggal 13 Agustus 2019. Akibat lain yang ditimbulkan oleh kebakaran rumah adalah dapat merenggut korban jiwa serta kerugian material bahkan kebakaran ini juga mampu merusak lingkungan sekitar dan gangguan kesehatan akibat dari asap kebakaran.

Ketika terjadi kebakaran biasanya masyakat sekitar berbondong-bondong ikut memadamkan api, jika petugas kebakaran belum datang. Biasanya masalah yang sering terjadi di tempat kejadian perkara adalah sering terlambatnya petugas pemadam kebakaran dilokasi kebakaran. Hal ini bias disebabkan oleh kurangnya kesiap siagaan petugas kebakaran dan terlambatnya informasi mengenai kebakaran yang disampaikan oleh pemilik rumah ataupun bahkan aparat pemerintahan yang ada dilokasi kebakaran. Dari masalah ini, maka yang menjadi titik perhatian penulis adalah kurangnya kesiapsiagaan petugas dan terlambatnya informasi yang diterima dari si pemilik rumah.

\section{KAJIAN PUSTAKA}

Banyak sistem deteksi kebakaran yang dibuat oleh peneliti sebelumnya diantaranya[2],[3],[4]. Masingmasing peneliti pada inti penelitian mereka mengindikasi suatu peristiwa kebakaran dengan peringatan dini, pengontrolan dengan mikrokontroler serta terintegrasi dengan smartphone dan aplikasi online berbasis web. Dengan alat bantu berupa sensor asap, sensor api serta sensor suhu

Perbedaan penelitian sebelumnya dengan yang dibuat adalah pada saat terjadi kebakaran, informasi kebakaran dikirim ke satuan pemadam kebakaran berupa sms dengan menunjukkan lokasi berupa link google maps dan titik koordinat. Dalam penelitian ini juga mengunakan tiga buah sensor yakni sensor api (flame sensor), sensor asap (MQ-2) dan sensor suhu (LM35).

\section{METODE}

\section{a. Arduino Uno}

Arduino Uno seperti pada gambar 1, adalah sebuah perangkat keras mikrokontroler yang berbasis open source. Mikrokontroler ini dapat dikembangkan lagi oleh pihak ketiga dalam mnegembangkan berbagai proyek pengendalian. Mikrokontroler ini juga digunakan dalam penelitian yang mengembangkannya dalam pengendalian suatu suatu proyek. [5], [6], [7].

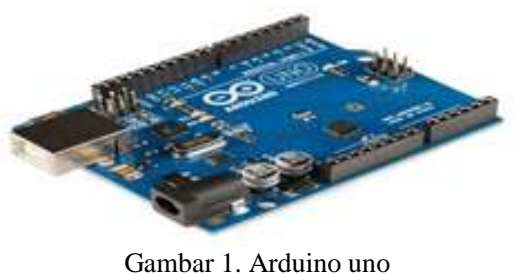

\section{b. Modul GSM SIM800L}

Banyak sekali aplikasi-aplikasi yang menggunakan modul GSM SIM800L. Diantaranya pengontrolan suatu proyek yang menggunakan informasi berupa sms, sehingga dengan informasi sms ini dapat menyalakan atau mematikan suatu sistem dalam pengontrolannya misalnya kontrol lampu rumah, kontrol level dan lain sebagainya. Bentuk fisik dari modul GSM SIM800L dapat dilihat pada gambar 2 .

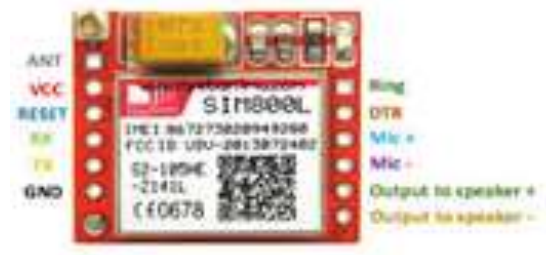

Gambar 2. SIM800L

\section{c. Modul GPS}

Pendeteksian suatu lokasi atau titik koordinat adalah memberikan informasi mengenai keadaan lokasi tersebut dalam suatu proyek dengan menggunakan sistem pengontrolan mikrokontroler. Piranti yang digunakan adalah modul GPS dengan tipe uBlox NEO-6M yang diperlihatkan pada gambar 3. Dimana dengan piranti ini fungsi utamanya adalah memberikan informasi berupa lokasi suatu kejadian dengan menunjukkan titik koordinatnya.

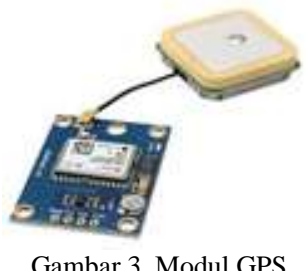

\section{d. Flame sensor}

Range panjang gelombang untuk flame sensor adalah $760 \mathrm{~nm} 1100 \mathrm{~nm}$ mendeteksi nyala api. Sensor ini juga bisa mendeteksi suhu panas dari $25^{\circ} \mathrm{C}$ sampai $85^{\circ} \mathrm{C}$ dengan jarak deteksi api adalah $100 \mathrm{~cm}$ yang menghasilkan keluaran sensor berupa tegangan 0,5 volt dan tegangan 5 volt untuk jarak deteksi terhadap objek 20 $\mathrm{cm}$.

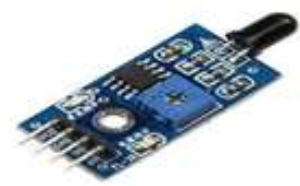

Gambar 4. Flame sensor

\section{e. Sensor MQ-2}

Salah satu sensor untuk mendeteksi gas adalah sensor MQ-2. Ketika akan digubungkan dengan mikrokontroler sensor ini penggunaannya sangat mudah penggunaannya. Seperti yang diperlihatkan pada gambar 5 merupakan bentuk fisik dari sensor MQ-2. Sensor MQ-2 memiliki piranti kecil dilengkapi dengan alat pemanas yang 
berinteraksi dengan beberapa jenis gas bereaksi dengan sensor kimiawi untuk menhasilkan keluaran dengan tingkat densitas gas yang dapat terdeteksi. Sensor ini baik sekali dalam berbagai aplikasi lebih khusus untuk mendeteksi gas.

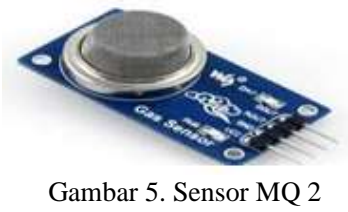

\section{f. Sensor Suhu LM35}

Untuk mendeteksi suatu suhu maka digunakan sensor suhu dengan tipe LM35. Kegunaan dari sensor ini adalah untuk mengubah besaran suhu jadi besasan listrik dalam bentuk tegangan. Sensor Suhu LM35 diperlihatkan pada gambar 6 yang juga digunakan dalam penelitian pengendalian suhu telur dalam ruangan prototipe. [8]

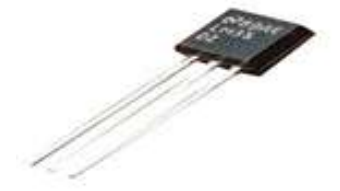

Gambar 6. Sensor suhu LM35

\section{g. LCD (Liquid Crystal Display)}

Piranti LCD sering digunakan dalam menampilkan angka maupun teks dalam suatu proyek, yang sering digunakan bersama dengan pengontrol seperti mikrokontroler. Bentuk fisik dari LCD dapat dilihat pada gambar 7. LCD yang digunakan adalah LCD 16x2 yang artinya lebar display 2 baris 16 kolom dengan 16 Pin konektor.

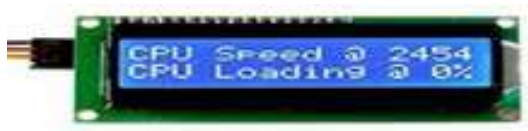

Gambar 7. LCD

\section{h. METODE}

Metode yang digunakan dalam penelitian ini adalah eksperimen dan perancangan yang sejalan dengan penelitian [9]. Eksperimen yang dilakukan adalah dengan memperhatikan bagaimana sensor yang digunakan berfungsi sesuai dengan fungsinya. Sementara untuk perancangan yang dilakukan adalah perancangan perangkat keras dan perangkat lunak. Perangkat keras ada yang sebagai alat pengirim, alat penerima serta sistem kontrolnya yang dapat mengontrol perangkat keras dan perangkat lunak.

Diagram blok perancangan sistem seperti diperlihatkan pada gambar 8. Dalam perancangannya terdiri dari blok pengirim dan blok penerima serta didukung dengan komponen lainnya seperti sensor, arduino uno. Dari sisi pengirim ketika 3 buah sensor yakni sensor api, sensor asap dan sensor suhu mendeteksi sesuai dengan fungsinya maka akan menyalakan buzzer dan menampilkan teks adanya kebakaran pada LCD. Kemudian akan memberikan informasi mengenai koordinat GPS dan mengirimkan sms data latitude dan longitude beserta link google maps yaitu berupa https://maps.google.com/maps?q= (latitude),(longitude).

Dari sisi blok penerima modul SIM800L, menerima informasi berupa sms "ON" alat akan menyalakan buzzer untuk memberitahukan adanya kebakaran, sehingga petugas pemadam kebakaran yang mengetahui informasi ini akan langsung menuju lokasi kebakaran.

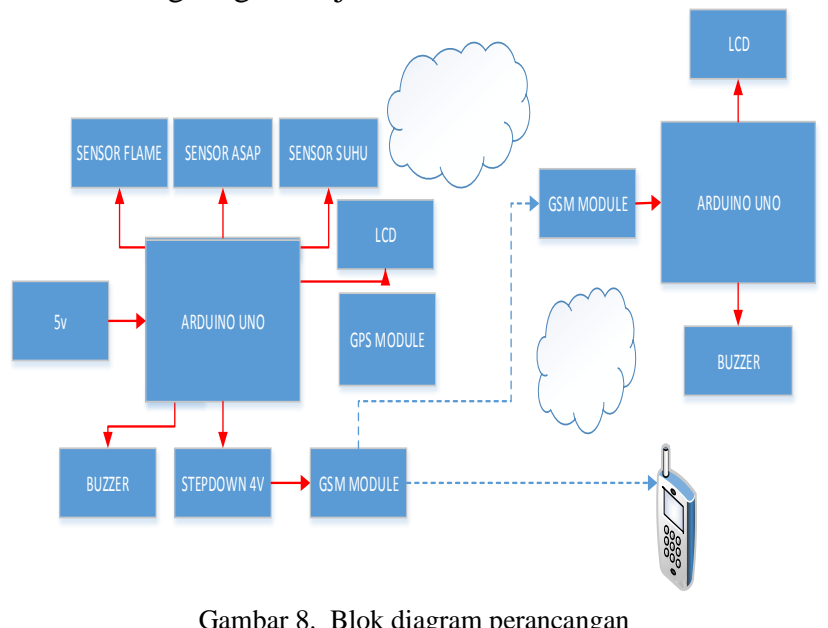

i. flowchart perancangan alat pengirim

flowchart perancangan alat pengirim yang digunakan dalam penelitian ini diperlihatkan pada gambar 9

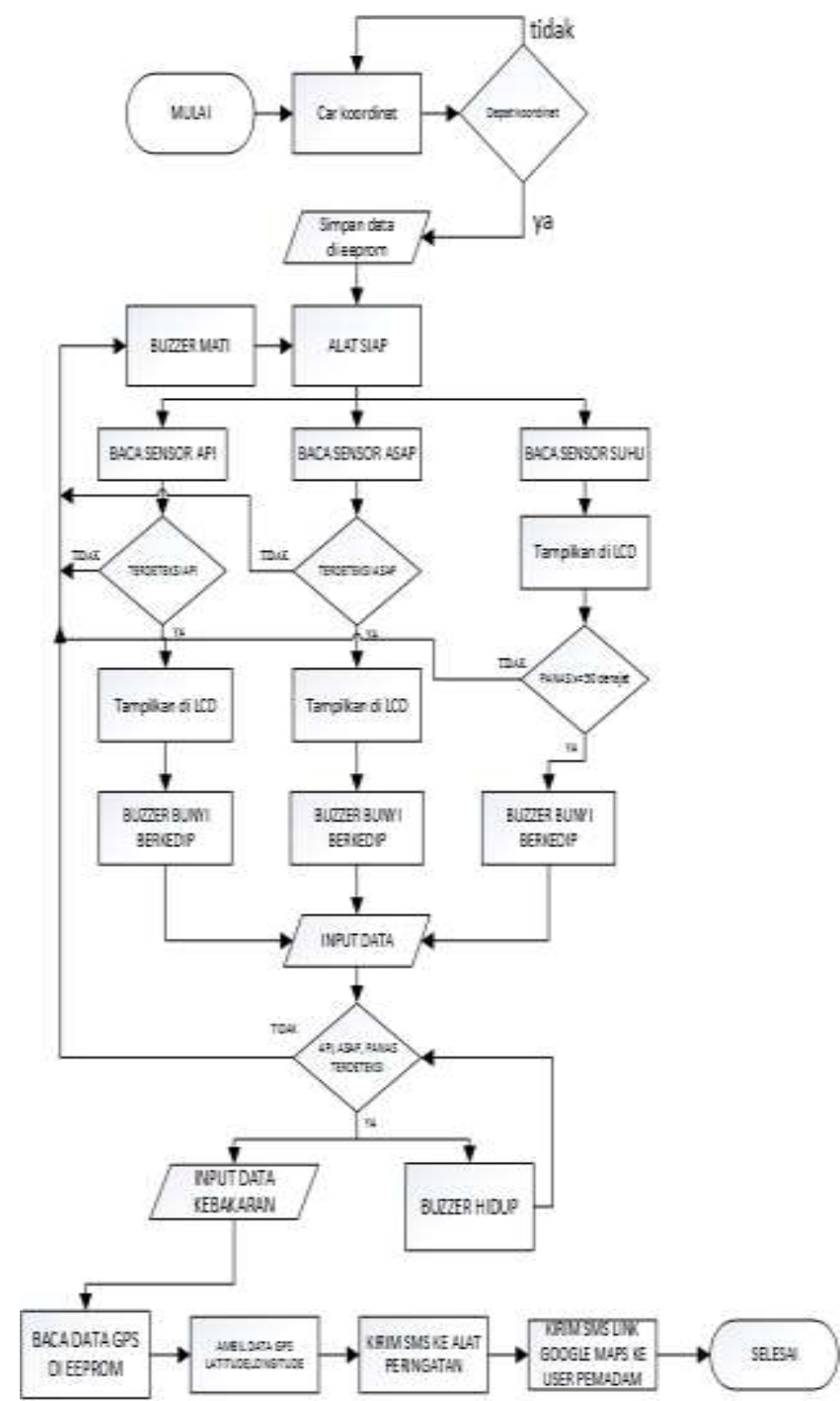


Untuk gambar 9 dapat dijelaskan sebagai berikut : Saat alat dinyalakan, dan menekan tombol push button, alat akan membaca data gps koordinat pada lokasi ditempatkannya alat; Setelah koordinat telah di temukan alat akan menyimpan data koordinat dengan menekan tombol push button; Alat akan membaca sensor api, asap dan suhu; Pada pembacaan sensor, jika salah satu sensor mendeteksi adanya api, asap ataupun suhu maka maka buzzer akan berbunyi berkedip dan menampilkan keterangan pada LCD bahwa alat mendeteksi adanya api, asap maupun suhu diatas 50 derajat. Alat belum bisa mengindikasikan bahwa ruangan sedang terbakar jika hanya salah satu atau dua sensor yang bekerja; Jika sensor sudah tidak mendeteksi, buzzer akan mati dan alat kembali siap; Apabila sensor mendeteksi adanya api, asap dan suhu sekaligus, maka alat akan membaca input data dari sensor, menyalakan buzzer dan menampilkan adanya kebakaran pada LCD; Alat akan membaca koordinat GPS yang telah tersimpan pada arduino dan mengirimkan sms data latitude dan longitude beserta link google maps yaitu berupahttps://maps.google.com/maps?q=(latitude),(longi tude). Dan alat akan mengirimkan akan mengirimkan sms kedua yaitu berupa sms "ON" untuk menyalakan pada alat penerima; Apabila sensor sudah tidak mendeteksi adanya api, asap dan suhu, buzzer akan mati dan alat kembali siap.

\section{j. Flowchat perancangan alat penerima}

Flowchat perancangan alat penerima bisa dilihat pada gambar 10.

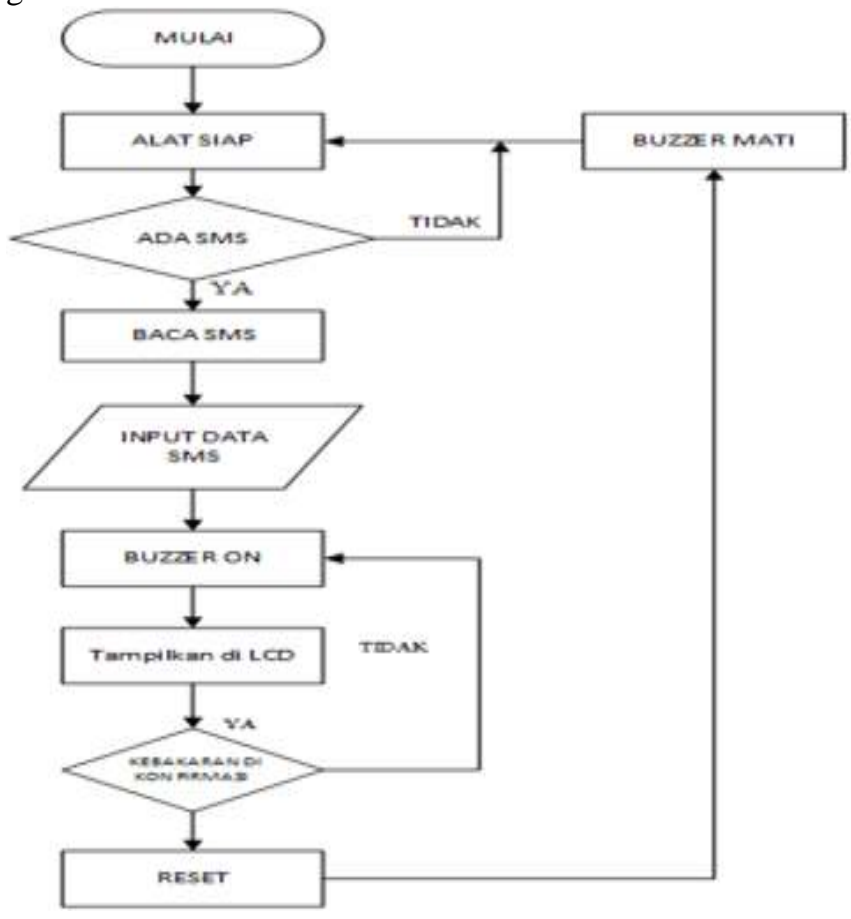

Gambar 10. flowchart perancangan alat penerima

Penjelasan gambar 10 sebagai berikut: Saat alat siap SIM800L ready; Saat alat menerima sms, alat akan menginput data sms yaitu berupa sms "ON" dan alat akan menyalakan buzzer untuk memberitahukan adanya kebakaran agar petugas pemadam kebakaran akan melihat handphone user yang sudah dikirimkan sms data koordinat pada alamat terjadinya kebakaran; Jika kebakaran belum dikonfirmasi dengan menekan tombol RESET maka buzzer pada alat akan terus menyala; jika kebakaran telah dikonfirmasi dengan menenekan tombol RESET maka alat akan kembali ke kodisi normal dan alat kembali siap.

\section{HASIL DAN PEMBAHASAN}

\section{A. Hasil Pengujian Perangkat keras}

Alat yang telah dirancang secara keseluruhan menjadi suatu sistem Selanjutnya dilakukan eksperimen dengan menguji coba dengan test pengoperasian alat dengan dua cara yakni menguji coba dengan mengetest komponen perangkat keras. Gambar secara keseluruhan perangkat keras sistem alat pengirim ditunjukkan pada gambar 11 dan alat penerima diperlihatkan pada gambar 12 .

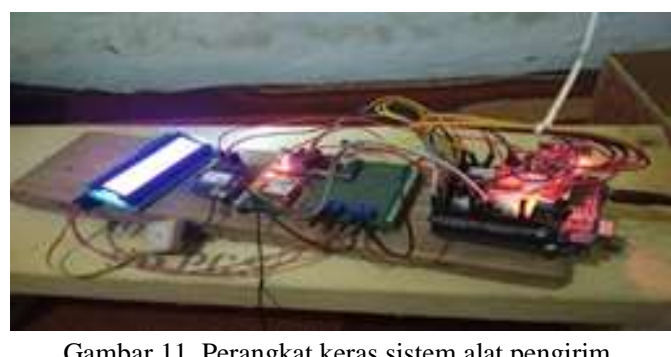

Gambar 11. Perangkat keras sistem alat pengirim.

Komponen yang digunakan pada gambar 11 sebagai perangkat pengirim berupa sensor api, sensor asap dan sensor suhu, buzzer, LCD, modul GPS dan arduino uno.

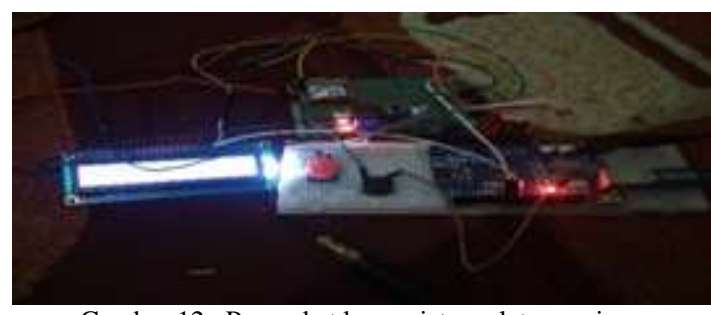

Gambar 12. Perangkat keras sistem alat penerima

Gambar 12 merupakan perangkat penerima informasi kebakaran yang komponenenya diantaranya modul gsm SIM800L, buzzer, LCD,

\section{B. Cara kerja pada alat pengirim.}

Cara kerja pada GPS adalah untuk membaca koordinat lokasi ditempatkannya alat, yang pertama untuk mengakses GPS adalah dengan menekan dan tahan tombol push button bersamaan dengan memberikan sumber tegangan pada alat, maka alat akan mencari koordinat. GPS mencari data koordinat lokasi, setelah GPS mendapatkan titik koordinat maka alat akan menampilkan koordinat pada LCD sejalan dengan artikel [10]. 
Setelah koordinat GPS terbaca, untuk menyimpan data GPS, dengan menekan tombol push button dan data koordinat akan tersimpan pada eeprom Arduino uno.

Cara kerja pada sensor api yaitu saat api dinyalakan maka sensor akan mendeteksi api dan menyalakan buzzer dan menampilkan text "fire detected.

Cara kerja pada sensor asap yaitu saat diberikan asap maka sensor akan mendeteksi asap dan menyalakan buzzer dan menampilkan text "smoke detected".

Cara kerja pada sensor suhu yaitu membaca suhu pada ruangan dan menampilkan suhu ruangan pada LCD.

Pada saat suhu diatas 50 derajar, maka buzzer akan menyala dan menampilkan text "temp reach max" seperti pada gambar 13 .

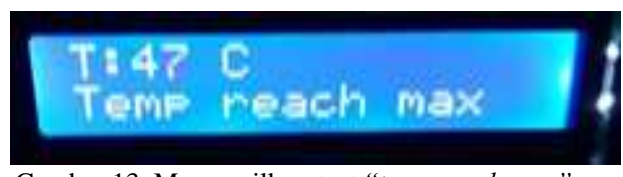

Gambar 13. Menampilkan text "temp reach max"

Cara kerja pada pengiriman sms yaitu saat keadaan adanya api, asap dan suhu di atas 50 derajat dan LCD akan menampilkan text "FIRE DETECTED".

Pada kondisi pembacaan adanya kebakaran, koordinat pada lokasi diduga adanya kebakaran akan dikirim beserta link google maps untuk dikirimkan pada handphone user satuan pemadam kebakaran. Gambar penerimaan sms link google maps bisa di lihat pada gambar 14 .

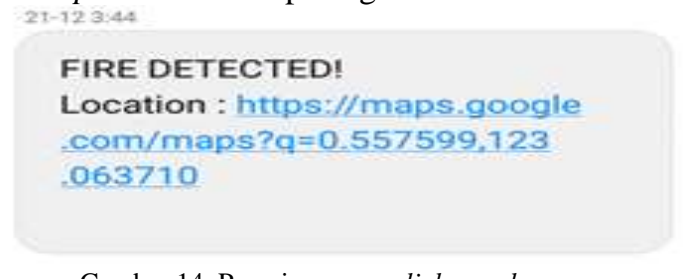

Gambar 14. Penerimaan sms link google maps

\section{Hasil pengujian pada alat penerima}

Pada saat alat penerima membaca adanya sms "ON" yang dikirim oleh alat pengirim, maka alat akan menyalakan buzzer dan menampilkan text pada LCD. Gambar text pada LCD bisa di lihat pada gambar 15 .

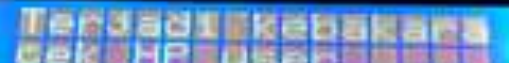

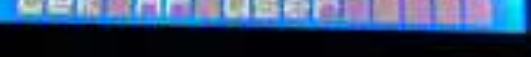

Gambar 15. Text pada LCD

Jika kebakaran telah dikonfirmasi oleh satuan pemadam maka alat akan direset dengan cara menekan tombol push button yang terdapat pada alat.

\section{Hasil Pengujian Perangkat Lunak (Software)}

Pada hasil pengujian software, software akan diuji untuk mengakses alat, untuk mengetahui apakah software bekerja dengan baik untuk mengakses alat. Selanjutnya dilakukan eksperimen dengan menguji coba dengan menguji pengoperasian alat dengan dua cara yakni menguji coba dengan menguji komponen perangkat keras.
Jika alat bekerja dengan baik dengan memakai program tersebut maka program dikatakan berhasil dan siap digunakan.

\section{E. PEMBAHASAN}

Berdasarkan hasil pengujian maka untuk perangkat keras terdiri dari alat pengirim informasi kebakaran dan alat penerima informasi kebakan. Dalam pengoperasian perangkat keras dan perangkat lunak saling saling berinteraksi antara satu dengan lainnya. Misalkan pada saat alat pengirim peringatan dini kebakaran akan menginformasikan peringatan kebakaran tersebut harus melewati sistem pengontrolan berupa mikrokontroler. Dimana mikrokontroler ini akan memberitahukan kembali pada alat penerima peringatan dini kebakaran dengan pemeritahuan lokasi terjadinya kebakaran. Respon terhadap kecepatan informasi kebakaran kepada pihak terkait seperti halnya dengan pengiriman sms pada umumnya. Dan hal ini sangat membantu pihat terkait untuk mendeteksi awal terjadinya kebakaran sehingga bahaya kebakaran yang merenggut banyak orang dapat dihindari.

\section{KESIMPULAN}

Berdasarkan hasil dari penelitian, maka dapat diambil kesimpulan sebagai berikut: Pada alat pengirim, Sebelum digunakan alat terlebih dahulu mencari data koordinat pada alamat dipasangnya alat. Sensor suhu akan mengirimkan data pada arduino jika suhu diatas 50 derajat. Sensor asap akan mengirimkan data pada arduino jika sensor mendeteksi adanya asap. Sensor api akan mengirimkan data pada arduino jika sensor mendeteksi adanya api. Jika ketiga sensor mendeteksi asap, api dan suhu diatas 50 derajat maka alat akan mengirim sms berupa sms "ON" untuk menyalakan alat penerima dan sms link google maps beserta data koordinat yang telah tersimpan pada handphone user pemadam kebakaran; Pada alat penerima, Jika alat menerima sms ON dari alat pengirim, maka alat akan menyalakan buzzer dan memberitahu informasi kebakaran. Untuk menkonfirmasi adanya kebakaran, alat akan di reset dengan tombol merah yang terdapat pada alat.

Saran, perlu menambah battery backup pada alat ketika terjadi pemadaman listrik saat kebakaran.

\section{REEFRENSI}

[1] BNPB, "B e ncana," Buku Saku Tanggap Tangkas Tangguh Mengahadapi Bencana, vol. 22, pp. 256-265, 2012.

[2] A. Fauzan, "Prototype Sistem Penanggulangan Kebakaran Berbasis Sms Gateway Menggunakan Mikrokontroler Arduino Uno," J. Teknol. Rekayasa, vol. 22, pp. 141-151, 2017.

[3] A. Faishal, M. Budiyanto, P. Diploma, and T. Elektro, "PENDETEKSI KEBAKARAN DENGAN MENGGUNAKAN SENSOR," vol. 2010, no. semnasIF, pp. 44-50, 2010.

[4] H. Saman, M. Jamil, and H. Saifudin, "Sistem Peringatan Dini Kebakaran Menggunakan 
Infrared Flame Detector Pararel Dengan Arduino GSM / GPRS Shield," vol. 04, no. 1, pp. 47-52, 2017.

[5] W. Ridwan, I. Z. Nasibu, R. D. R. Dako, and I. Wiranto, "Sistem Pemantauan Dan Pengendalian Penerangan Rumah Berbasis Web Menggunakan Raspberry Pi,” Semin. Nas. Tek. Elektro, vol. 1, no. 1, p. 225, 2017.

[6] Y. H. Kanoi, S. Abdussamad, and S. W. Dali, "Perancangan Jam Digital Waktu Sholat Menggunakan Arduino Uno," Jambura J. Electr. Electron. Eng., vol. 1, no. 2, pp. 32-39, Oct. 2019.

[7] A. W. A. Antu, S. Abdussamad, and I. Z. Nasibu, "Rancang Bangun Running Text pada Dot Matrix 16X160 Berbasis Arduino Uno Dengan Update Data System Menggunakan Perangkat Android Via Bluetooth," Jambura J. Electr. Electron. Eng., vol. 2, no. 1, pp. 8-13, Jan. 2020.

[8] M. R. Wirajaya, S. Abdussamad, and I. Z. Nasibu, "Rancang Bangun Mesin Penetas Telur Otomatis Menggunakan Mikrokontroler Arduino Uno," Jambura J. Electr. Electron. Eng., vol. 2, no. 1, pp. 24-29, Feb. 2020.

[9] S. Abdussamad, "Rancang Bangun Inverter Mini $1.5 \mathrm{Vdc}$ to 220 Vac Untuk Lampu Darurat," $J$. Tek., vol. 18, no. 1, pp. 7-16, Jun. 2020.

[10] Z. Purnomo, J. Karim, B. Senung, and S. Abdussamad, "Sistem Informasi Jasa Pemesanan Percetakan Berbasis Android," Jambura J. Electr. Electron. Eng., vol. 2, no. 2, pp. 44-51, Jul. 2020. 